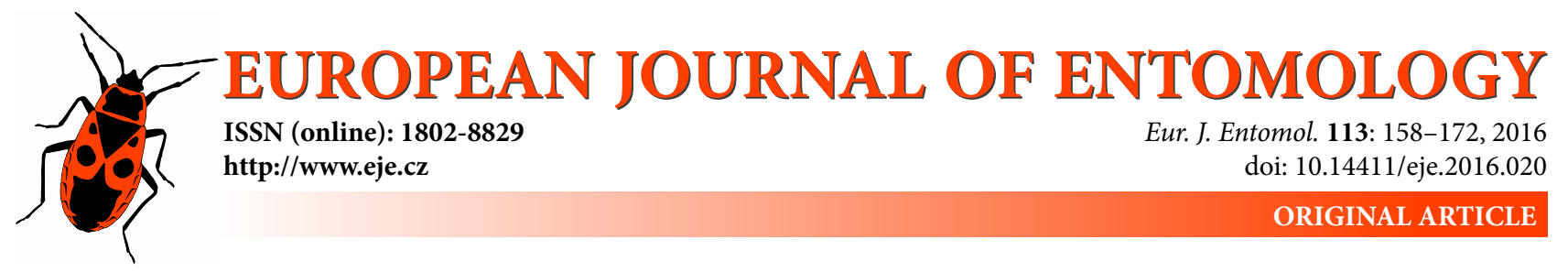

\title{
Diversity of grasshoppers (Caelifera) recorded on the banks of a Ramsar listed temporary salt lake in Algeria
}

\author{
Sarah MAHLOUL ${ }^{1}$, Abboud haRRAT ${ }^{1}$ and Daniel PETIT ${ }^{2,}$ * \\ ${ }^{1}$ Laboratoire de biosystématique et écologie des arthropodes, Université Mentouri Constantine I, route d'Ain-El-Bey, 25000 \\ Constantine, Algeria; e-mails: sarah.mahloul@gmail.com, abboud52@yahoo.fr \\ ${ }^{2}$ UMR 1061 INRA, Université de Limoges, 123, avenue A. Thomas, 87060 Limoges cedex, France; e-mail: daniel.petit@unilim.fr
}

Key words. Caelifera, grasshopper, Dericorys, Calliptamus, temporary salt lake, halophytes, food sources, dispersal, Algeria

\begin{abstract}
The chotts in Algeria are temporary salt lakes recognized as important wintering sites of water birds but neglected in terms of the diversity of the insects living on their banks. Around a chott in the wetland complex in the high plains near Constantine (eastern Algeria), more than half of the species of plants are annuals that dry out in summer, a situation that prompted us to sample the vegetation in spring over a period of two years. Three zones were identified based on an analysis of the vegetation and measurements of the salt content of the soils. Surveys carried out at monthly intervals over the course of a year revealed temporal and spatial variations in biodiversity and abundance of grasshoppers. The inner zone is colonized by halophilic plants and only one grasshopper species (Dericorys millierei) occurs there throughout the year. Two polyphagous species of Calliptamus, which can feed on halophilic plants migrate from adjacent areas into the inner zone in August to feed on the plants growing there. The other species of grasshoppers remain in outer zones as they are unable to feed on halophilic plants. The greatest abundance of grasshoppers from August to winter was recorded in the inner zone and in spring and early summer in the outer zones. The dependence of $D$. millierei on bushes of Amaranthaceae and its moderate flight ability, features of the family Dericorytidae, limit this species ability to colonize neighbouring chotts.
\end{abstract}

\section{INTRODUCTION}

Wetlands in the Mediterranean basin are rare and their estimated total surface area is $21,000 \mathrm{~km}^{2}$, of which 4,700 $\mathrm{km}^{2}$ are coastal lagoons, $2,800 \mathrm{~km}^{2}$ freshwater lakes and marshes and $11,600 \mathrm{~km}^{2}$ temporary salt lakes, the last of which occur mainly in North Africa (Britton \& Crivelli, 1993).

In dry parts of North Africa, sebkhas and chotts are continental depressions occupied by salty temporary lakes, which are the result of a combination of torrential rain storms and rapid runoff in quasi-desert landscapes. These areas are not only breeding and over wintering sites for birds but also feeding and resting sites for numerous species of birds that annually migrate between Africa, northern Europe and Asia (Houhamdi et al., 2009). These features reflect the high biological quality of these sites and many of them are protected by the Ramsar Convention. There is a need to record the biodiversity at these sites and develop effective strategies for their conservation.

Among the North African wetlands of international importance, the chott complex on the Constantine plateau in eastern Algeria is located between the wilayas of Oum-El-
Bouagui, Batna and Khenchela. There are fifteen chotts and sebkhas of which 9 are listed under the Ramsar Convention, which span a distance of $300 \mathrm{~km}$, and cover an area of 55,000 ha, at altitudes between 800 and $1200 \mathrm{~m}$ a.s.l., and the water is characteristically shallow and more or less salty. Their banks are colonized by permanent vegetation with islands of greenery whenever water is present. Plant communities around chotts occur in more or less distinct zones, defined in terms of the ability of the plants to tolerate salinity, floods and competition (Pennings et al., 2005).

These vast wetlands are monitored regularly in terms of the aquatic birds since the discovery of flamingos nesting in this region. In contrast, the terrestrial habitats contiguous with the wetlands are often ignored or undervalued by scientists. The fauna and flora was neglected, especially the insect fauna living on the vegetation surrounding the salt lakes, in spite of their vital role in sustaining biological diversity on a global basis. Grasshoppers (Caelifera: Acridomorpha) are recognized as a very important source of mainly protein food for birds (Massa, 1978; Pantone et al., 1999; Si Bachir et al., 2001; Jiguet, 2002; Souttou et al., 2007). They are also important bio-indicators because

\footnotetext{
* Corresponding author; e-mail: daniel.petit@unilim.fr
} 


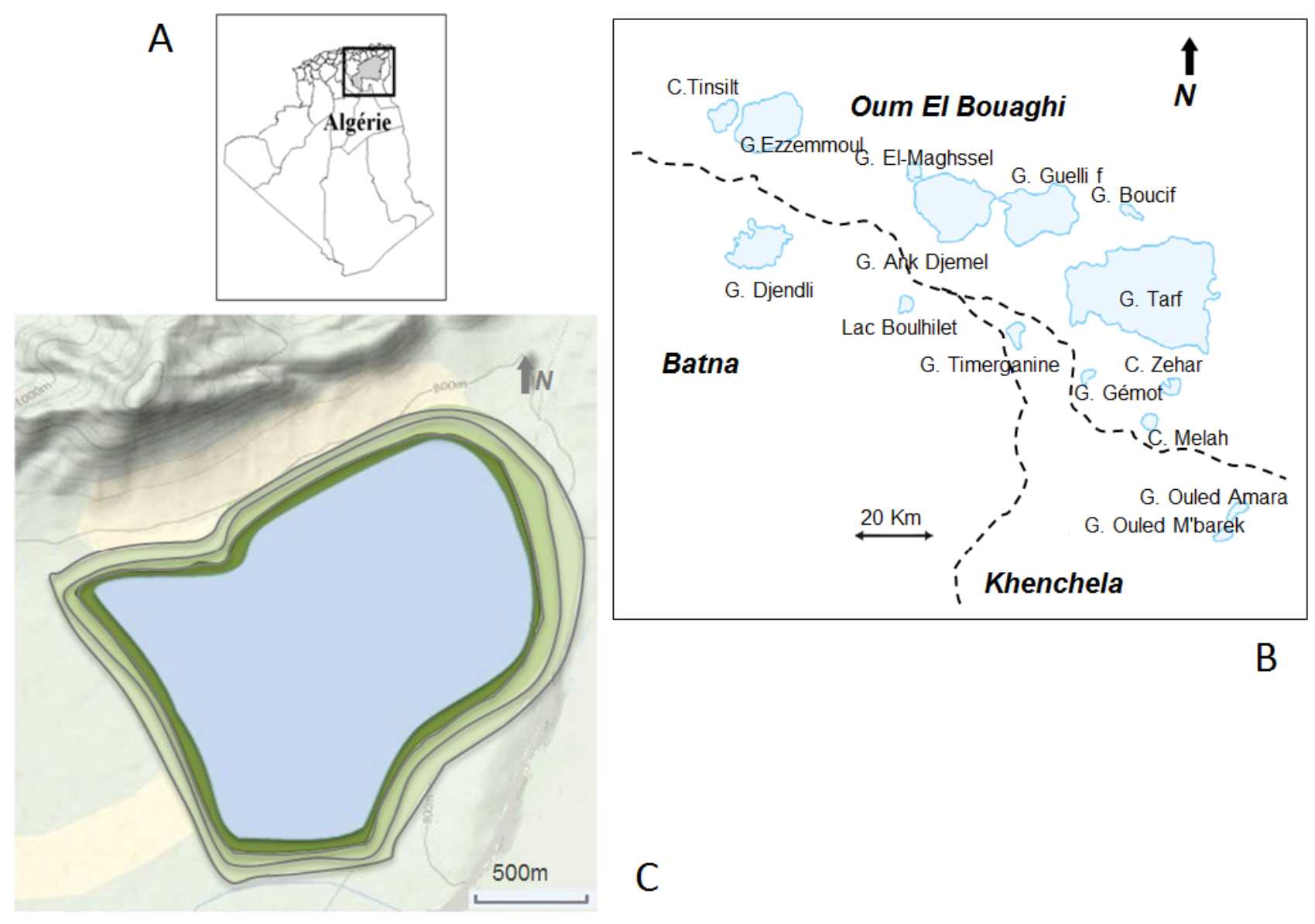

Fig. 1. Location of chott Tinsilt. A - location in Algeria; B - the chott and sebkha complex on the southern part of the Constantine plateau. Most salt lakes are in Oum-El-Bouaghi Wilaya. C - diagram showing the three zones around chott Tinsilt.

of their specific microhabitat preferences and sensitivity to any changes in their habitats (Guido \& Gianelle, 2001).

Our first goal was to describe the composition of grasshopper assemblages in the different plant zones and seasons. Given the dependence of grasshopper assemblages on the structure and type of vegetation in Algeria (Guendouz-Benrima et al., 2011; Moussi et al., 2011; Sobhi et al., 2013) and Europe (Bonnet et al., 1997), it was first necessary to describe the vegetation and soil. In particular, we focused on the monthly changes in salt concentrations at different depths in the soil in relation to variations in climate. Our second aim was to investigate the possible movement of species between the different zones taking certain factors into consideration. First, the progressive drying out of the vegetation during spring, which affects outer zones first and then the inner ones. So we expected the species in the outer zones to move into the inner zones at the end of spring in order to find areas where the humidity is higher and there are living plants. Second, since plants growing in the inner zones are generally halophytes and grow in soil that is wet most of the year, there could be a problem in terms of the food there as most species of grasshoppers feed on grasses, i.e. Poaceae and allied families (Uvarov, 1977). So it is questionable whether the grasshoppers in the inner zone can feed on the plants there, or alternatively move frequently to outer zones to find edible plants. In order to address this problem we studied their ability to move between zones and the diets of the most abundant species in the three zones using the methods adopted in previous studies (Ben Halima et al., 1984, 1985; Mokhlesse et al., 2007; Picaud \& Petit 2007). Regarding the cycle (Benfekih \& Petit, 2010; Guendouz-Benrima et al., 2011; Moussi et al., 2011), comparison between species will be addressed in another paper. Finally, the analyses revealed the species that were most threatened by the changes occurring in these areas.

\section{MATERIAL AND METHODS}

\section{Site description}

Chott Tinsilt is $5 \mathrm{~km}$ south east of Souk-Naâmane and $17 \mathrm{~km}$ south of the town of Ain-M'lila (35 $53^{\prime} 14^{\prime \prime} \mathrm{N}, 6^{\circ} 28^{\prime} 44^{\prime \prime} \mathrm{E}$, OumEl-Bouaghi Wilaya), with a surface of 2154 ha and a maximum altitude of $792 \mathrm{~m}$ a.s.l. It is part of the wetland complex of the high plains of eastern Algeria (Fig. 1). The watershed is 10,300 ha in area and includes rainwater from Oued Ben Zerhaïb and wastewater from the village of Souk-Naâmane. Water is lost from this area via evaporation and southwest drainage canals that flow into a discharge channel that goes as far as the nearby Sebkhat Ezzemoul. Chott Tinsilt is dry or occasionally flooded depending on the year and the amount of rainfall. The maximum depth is usually $0.5 \mathrm{~m}$, but the water level is subject to significant fluctuations depending on rainfall, temperature and wind. During the years 2013-2014, the chott was flooded in autumn, winter and early spring.

The soil consists of Quaternary sedimentary clays and silts rich in limestone. According to Boumezbeur \& Khalfallah (2005), the 


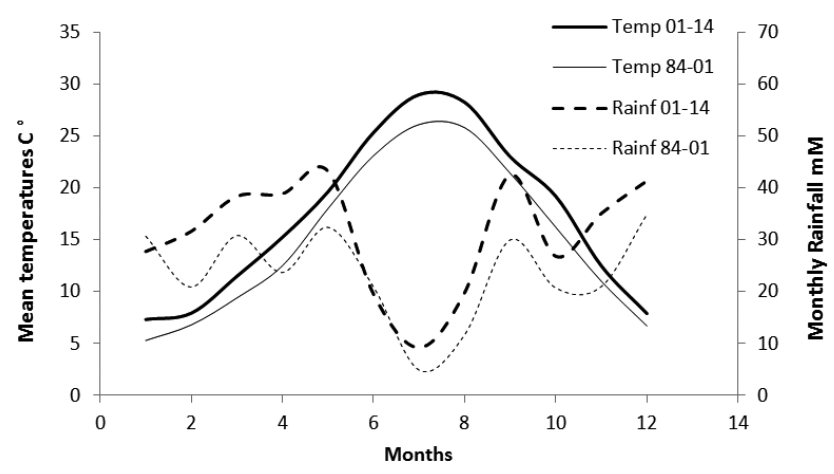

Fig. 2. Ombrothermic diagram of Gaussen based on meteorological data collected at Oum-El-Bouaghi. Thick lines: period 2001-2014; thin lines: period 1984-2001. Continuous lines: mean monthly temperatures. Dashed lines: mean monthly rainfall.

inner edges of the chott are usually wetter than the dryer outer edges. These edges are covered with herbaceous vegetation, which consists of salt-tolerant plants, belonging mainly to two large families, Amaranthaceae and Aizoaceae (Mesembryanthemum nodiflorum, Salicornia arabica, Arthrocnemum glaucum and Atriplex sp).

Data on the climate in the period 1984-2014 was obtained from the Algerian Meteorological Office. This data was split into two periods (1984-2001 and 2001-2014). The average temperatures and monthly precipitation in this data set was used to plot a climatogram using Gaussen's method (Bagnouls \& Gaussen, 1953). The months in which the rainfall curve is below the temperature curve are considered as dry months (Fig. 2). The dry season is from April to September in the first and from May to November in the second period, the maximum temperatures were recorded in July. This is supported by monthly aridity indices, $\mathrm{AIi}$, obtained using the formula $\mathrm{AIi}=\mathrm{ETPi} / \mathrm{Ri}$, where ETPi is the Potential Evaporation for month $\mathrm{i}$, and Ri the rainfall for the same month. As the data needed for calculating Penman's evaporation index (1948) are lacking, we used the estimate given by Thornthwaite (1948). In both periods, the driest months are the same and run from May to October with AIs below 0.5 (Appendix 1). In September there are sudden rain showers that affect the area and fill the temporary chotts, but the water quickly disappears due to evaporation or drainage. There is no tendency toward increasing aridification over the last 30 years, although a recent study indicated an increase in mean maximal temperatures in this region over the period 1980 to 2010 (Petit, 2014). If we take into account more ancient data, the mean annual rainfall was $449 \mathrm{~mm}$ in the 20 year period ending in 1946 (Seltzer, 1946), which is characteristic of a semi-arid climate. In the more recent years, $282 \mathrm{~mm}$ (1984-2001) and $374 \mathrm{~mm}$ (2001-2014) were recorded, which is indicative of an arid climate (Le Houérou, 2001).

\section{Soil sampling}

In each zone and on each date sampled, 8-10 soil subsamples were collected at intervals of $10 \mathrm{~m}$ and then combined, the "final" sample. Depths sampled were 5, 10 and $20 \mathrm{~cm}$. The samples were collected monthly from March to September 2014. Each sample was reduced to $500 \mathrm{~g}$ fresh weight and kept in a plastic bag. The particle size recorded in the different zones did not differ significantly and consisted of fine particles without gravel.

The $\mathrm{Cl}^{-}$and $\mathrm{SO}_{4}^{2-}$ was quantified using aqueous extractions of soil (sieved to $2 \mathrm{~mm}$ ) obtained using 2 volumes of distilled water to one of soil (Mathieu \& Pieltain, 2003). The chloride was determined using a solution of silver nitrate and the formula:

$\mathrm{Cl}^{-}\left(\mathrm{g} . \mathrm{L}^{-1}\right)=\mathrm{V} \times \mathrm{D}$ with: $\mathrm{V}=$ volume in $\mathrm{ml}$ of silver nitrate needed to measure the chloride content, $\mathrm{D}=$ dilution level (10 or 100$)$. The quantity of $\mathrm{SO}_{4}^{2-}$ was determined using an absorbance spectrophotometer (JENWAY 7300).

$\mathrm{Na}^{+}$was quantified using the filtrate recovered from soil saturated with ammonium acetate (1/2 vol) and a flame photometer (SHERWOOD M 410) using the following equation:

$$
N a\left(g \cdot k^{-1}\right)=R \frac{V}{G} \times \frac{100}{1000}
$$

for which $\mathrm{R}$ is obtained from the standard curve, $\mathrm{V}=$ volume of the filtrate $(250 \mathrm{ml}), \mathrm{G}=$ weight of the soil in $\mathrm{g}(20 \mathrm{~g})$.

\section{Description of the vegetation}

The zones of vegetation occur in belts of 20 to $150 \mathrm{~m}$ in width, i.e. in concentric zones around these temporary lakes. The boundaries between these zones are more or less precise, heavily influenced by the depth of the water, the importance of dry periods and salinity.

To provide quantitative data on plant abundances, we established five transects randomly within each zone following the method of Mayer (Oueld El Hadj, 2004). Briefly, counting of individuals of each species was done along a chord $10 \mathrm{~m}$ long. This was repeated five times in each zone with a distance of at least 10 $\mathrm{m}$ between transects. To limit errors in assessing ecological preferences of plants, the chords were placed into the center of each zone at some distance from the adjacent zone(s). Vegetation was surveyed between February and April in 2013 and 1014, when the annual species were present.

Plants were collected and placed in plastic bags and kept in newspaper for drying. A herbarium was created with records of the date collected, the zone and the name of the species. The identifications were done using the flora of Quézel \& Santa (1962, 1963 ) and the nomenclature updated using the Tela-botanica electronic flora database, section north Africa, available at the web address http://www.tela-botanica.org/page:bdafn?langue=fr. To determine plant communities, the phytosociological databases of Kaabeche (1996) and Julve (1998) were used.

\section{Sampling of grasshoppers}

For each zone, grasshopper diversity and abundance were estimated using quadrates of $100 \mathrm{~m}^{2}$ (square areas of $10 \times 10 \mathrm{~m}$ ). Six samples were recorded each month, two in each zone. Quadrates were randomly located in each zone. The sampling period was from March 2013 to September 2014 with one visit per month. For each survey, the square was searched from the periphery to the center along a concentric path (Gardiner et al., 2005), between $10 \mathrm{am}$ and $15 \mathrm{pm}$, i.e. at times of day when the grasshoppers are most active. Adult grasshoppers fleeing vegetation were captured using a sweep net or by hand. As the abundance was about 0.5 individuals per $\mathrm{m}^{2}$, this method of sampling was almost completely successful as less than $5 \%$ of the estimated number of individuals escaped and were not counted.

After identification, grasshoppers were usually immediately released in order to avoid impoverishing the environment. A small number of the critical species were collected for further examination in the laboratory, in particular the dissection of genitalia, essential for the identification of species of the family Pamphagidae (Benkenana et al., 2012). Determinations were done using the keys of Chopard (1943) and Massa (2013). The updating of the nomenclature was done using the websites of Eades et al. (2013) and Louveaux et al. (2013).

\section{Diet of grasshoppers}

Their diet was determined by a microscopic analysis of plant debris in the faeces of captured grasshoppers. This study was 
A
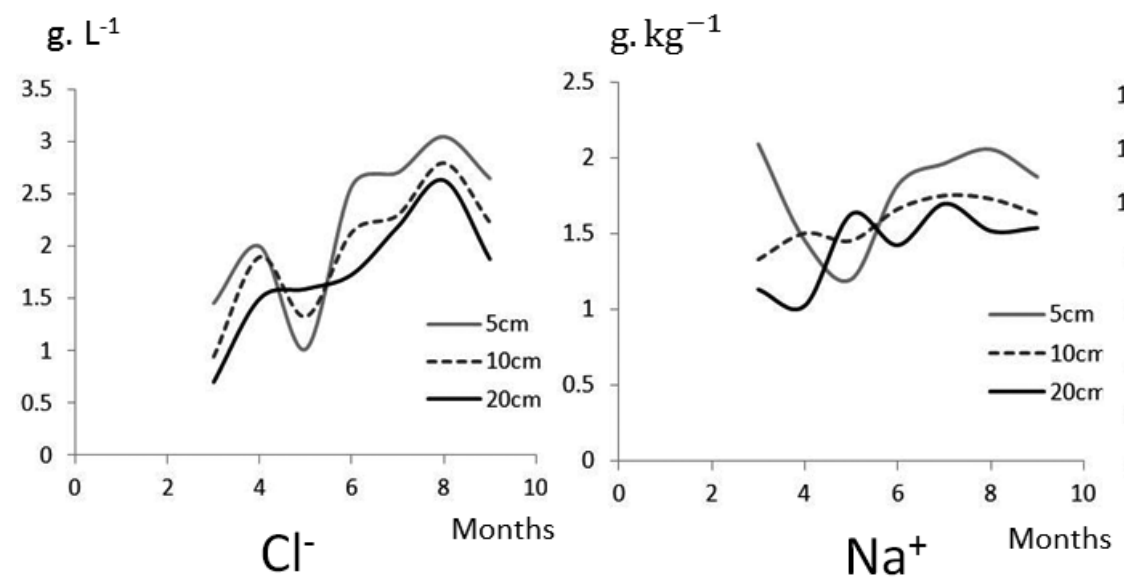

g. $L^{-1}$

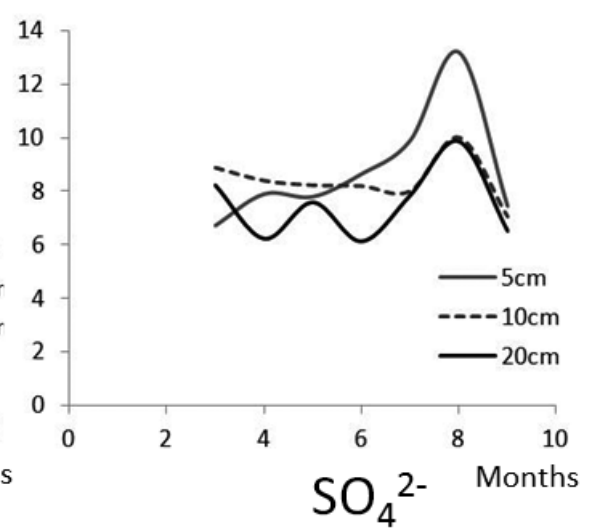

B

\section{g. $L^{-1}$}

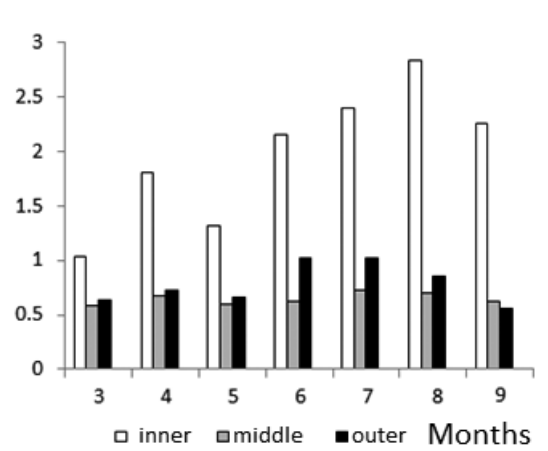

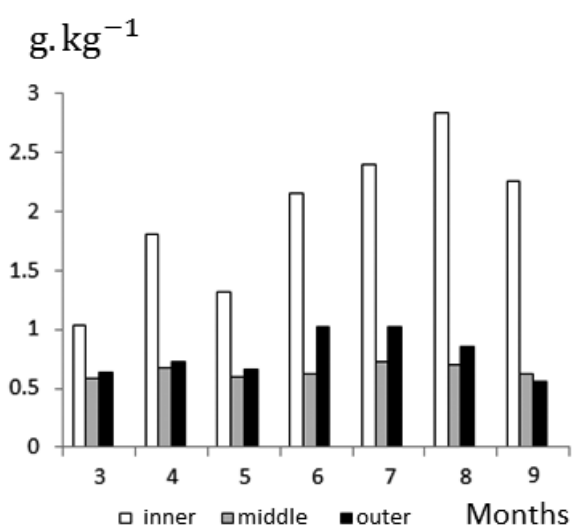

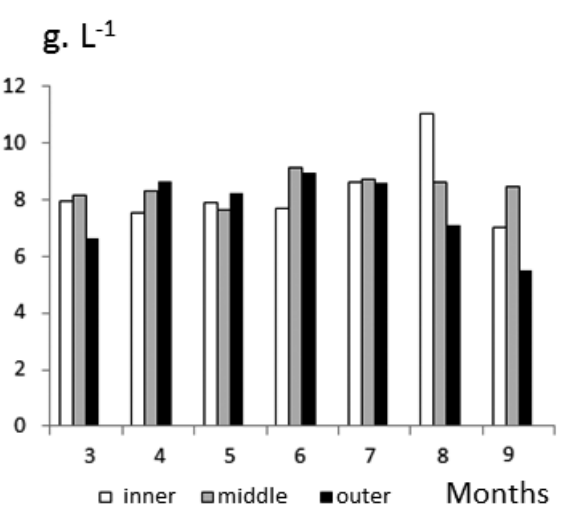

Fig. 3. Salinity in the three zones. A - salt concentrations recorded in the inner zone in different months and different depths in the soil; $B$ - average of the salinities recorded at the three depths in the three zones.

done for adults of two species: Dericorys millierei Bonnet \& Finot (1884), because it is the dominant species in the inner zone, and Calliptamus barbarus (Costa, 1836), which is abundant in the central zone. In May and June (mostly in 2013), 10 males and 10 females of both species were caught and placed separately for one hour in perforated tubes with small holes for ventilation.

Analysis of faeces and preparation of a reference collection of pieces of epidermis of the different plants in the area followed the methods described in Benkenana et al. (2013).

\section{Grasshopper movements}

The movements of adult grasshoppers encountered at the site were studied during the month of July, 2013. The lengths of the escape flights of 20 individuals of each species (10 males and 10 females) were measured using Picaud \& Petit (2007) and Mokhlesse et al. (2007) method. Individuals of both Calliptamus barbarus and Dericorys millierei were caught in the central zone and released in the same zone after marking them on the pronotum. Individuals usually hid at the bases of tufts of plants. The experimenter approached the refuge plant, which stimulated the grasshopper to escape by a flying leap and the distance it flew was then measured. This was repeated five times and the lengths of the successive jumps recorded.

\section{Morphometry}

We measured the morphological features of adult individuals collected during 2013. The lengths of the pronotum, hind femur, tegmina (until the radial rib disappeared under the pronotum) and abdomen (the ventral part) were measured using calipers or graduated paper (in $\mathrm{mm}$ ), under a binocular microscope. This proce- dure results in an accuracy of $1 / 10 \mathrm{~mm}$. The values obtained were recorded along with the species, sex and date collected. For each species and sex, at least ten individuals were measured.

\section{Data analyses}

Community indices for each zone (abundance, species richness, Shannon index) were calculated for plants and grasshoppers. The significance of differences was deduced from bootstrap and permutation methods (Poole, 1974). The signification level of the temporal and spatial variations in abundance was tested using One-Way ANOVA. The compositions of the communities in the three zones were compared using ANOSIM (Analysis of Similarity, see Clarke, 1993) with a single factor for vegetation (zone) and two factors for grasshoppers (season and zone). The Bray-Curtis coefficient was used as a distance measure.

To assess the vegetation types associated with each zone, we counted the number of species of plants assigned to each phytosociological class for each zone. We thus obtained a table with three columns and 13 lines ( 3 zones $\times 13$ phytosociological classes). This dataset was analyzed using Correspondence Analysis, which provided scores in two dimensions for each element. These scores were then analyzed using cluster analysis, with Euclidean distance as the distance measure. This procedure associated particular phytosociological classes with each zone (Kaabeche, 1996; Julve, 1998).

To determine the grasshopper assemblages, another Correspondence Analysis was done for each date sampled and zone. The scores of the first three axes were used for a cluster analysis, using Euclidean distance as distance measure. 


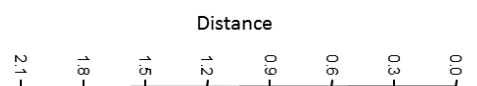

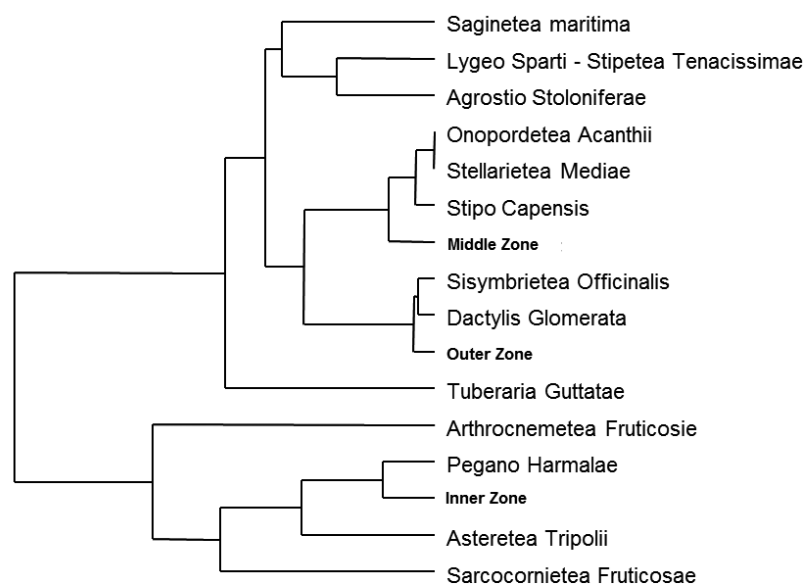

Fig. 4. Dendrogram of the phytosociological associations recorded in the three zones. The Euclidean distance was calculated based on the scores of the 2 first axes of Correspondence Analysis. See appendix 2 for the complete names of phytosociological associations.

The morphometrics of grasshoppers recorded in the different zones were compared using ANCOVA (body length taken as covariable) and MANOVA (the zones considered as a factor). All these operations were carried out using PAST software 3.17 (Hammer et al., 2001).

\section{RESULTS}

\section{Salinity}

In the inner zone (Fig. 3A), the content of $\mathrm{Cl}^{-}$was higher at the surface than at deeper levels with the exception of May when it was the opposite. The highest concentrations of $\mathrm{Cl}^{-}$were recorded in August. There were similar changes in the values of $\mathrm{Na}^{+}$, but the peak recorded in August was less pronounced. The highest concentration of $\mathrm{SO}_{4}^{2-}$ was also recorded in August. The curves of the concentrations, however, did not cross in March and there was very little difference in the concentrations recorded at the different depths.

To compare the salinity in the 3 zones, the average concentrations of each ion at the three depths were calculated (Fig. 3B). Chloride concentration was consistently higher in the inner zone than in the other two zones, where lower and very similar concentrations were recorded. There were high concentrations of $\mathrm{SO}_{4}^{2-}$ in the all three zones. For $\mathrm{Na}^{+}$ the concentrations were similar in March and April, but from May onwards the concentrations were higher in the inner zone than in the other two zones.

\section{Vegetation}

The vegetation in the three zones consisted of 60 species of plants belonging to 18 different families (Appendix 2). Poaceae and Asteraceae, with 12 and 14 species, respectively, made up half of the flora and there were four species of Amaranthaceae. The distribution of the species in the three zones reflects very closely their tolerance of salinity.

The vegetation in the three zones differed significantly in its richness and diversity, with the middle zone slightly
Table 1. Parameters of plant assemblages recorded in each zone. The different letters correspond to significant differences (permutation test).

\begin{tabular}{lccc}
\hline & Inner zone & Middle zone & Outer zone \\
\hline Taxa_S & $8 \mathrm{a}$ & $46 \mathrm{~b}$ & $31 \mathrm{c}$ \\
Sample rarefaction & 8 & 46 & 31 \\
Individuals & $187.80 \mathrm{a}$ & $292.40 \mathrm{~b}$ & $367.80 \mathrm{c}$ \\
Dominance D & $0.32 \mathrm{a}$ & $0.041 \mathrm{~b}$ & $0.048 \mathrm{~b}$ \\
Shannon H' & $1.27 \mathrm{a}$ & $3.46 \mathrm{~b}$ & $3.22 \mathrm{c}$ \\
\hline
\end{tabular}

more diverse than the outer zone, and the inner zone the poorest (permutation test, $\mathrm{p}<1 \%$ ). Dominance was lower in the two outer zones (permutation test, $\mathrm{p}<1 \%$ ), which reflects a more equal balance between species abundances (Table 1). The comparison of floras using ANOSIM (BrayCurtis as the distance measure, 10,000 permutations) revealed that the species composition in the three zones differed significantly $(\mathrm{p} \leq 0.01)$.

The cluster analysis of the phytosociological classes recorded in the three zones indicates that the inner zone is colonized by halophytic vegetation and salt tolerant species (Fig. 4). These species belong to classes of the Mediterranean to sub-desert chamaephytic halophiles (Pegano harmalae), littoral micro-mangroves (Sarcocornietea fruticosie), European salty meadows (Asteretea tripolii) and Mediterranean sansouires (Arthrocnemetea fruticosie).

Plants in outer and middle zones belong to the classes associated with the steppes (Lygeo sparti-Stipetea tenacissimae: five species) and to a lesser extent with subnitrophile therophytes (Saginetea maritima: two species) and European prairies (Agrostio stoloniferae: one species). In the middle zone the perennial xerophyte of fallow lands (Onopordetea acanthii: 10 species), annual weeds (Stellarietea mediae: six species) and other European therophytes (Stipo capensis Brachypodietea distachyi: five species) that occur in degraded steppes were recorded. In the middle zone, halophilic species are rare as only three species of plants that are tolerant of salt, namely Beta vulgaris ssp. maritima, Peganum harmala and Artemisia herba-alba, occurred there. The flora in the outer zone includes therophytes of fallow lands (Sisymbrietea officinalis: seven species) and Mediterranean grasslands (Dactylo glomeratae-Brachypodietea retusi: three species).

\section{Grasshopper assemblages}

A total of 3315 grasshoppers belonging to 17 species were recorded in the three zones. These species belong to four families: Pamphagidae, Pyrgomorphidae, Acrididae and Dericorythidae. Ten species of the family Acrididae were recorded in both the outer and middle zones and only species of the subfamily Calliptaminae were recorded in the inner zone. The four species of Pamphagidae and two of Pyrgomorphidae were recorded in the outer and middle zones. There was only one species of Dericorythidae recorded and only in the inner zone.

At the zone level, whether the main community parameters differed significantly was determined using permutation tests. The results in Table 2 indicate that significantly lower values were recorded in the inner zone (richness $\mathrm{S}$, 


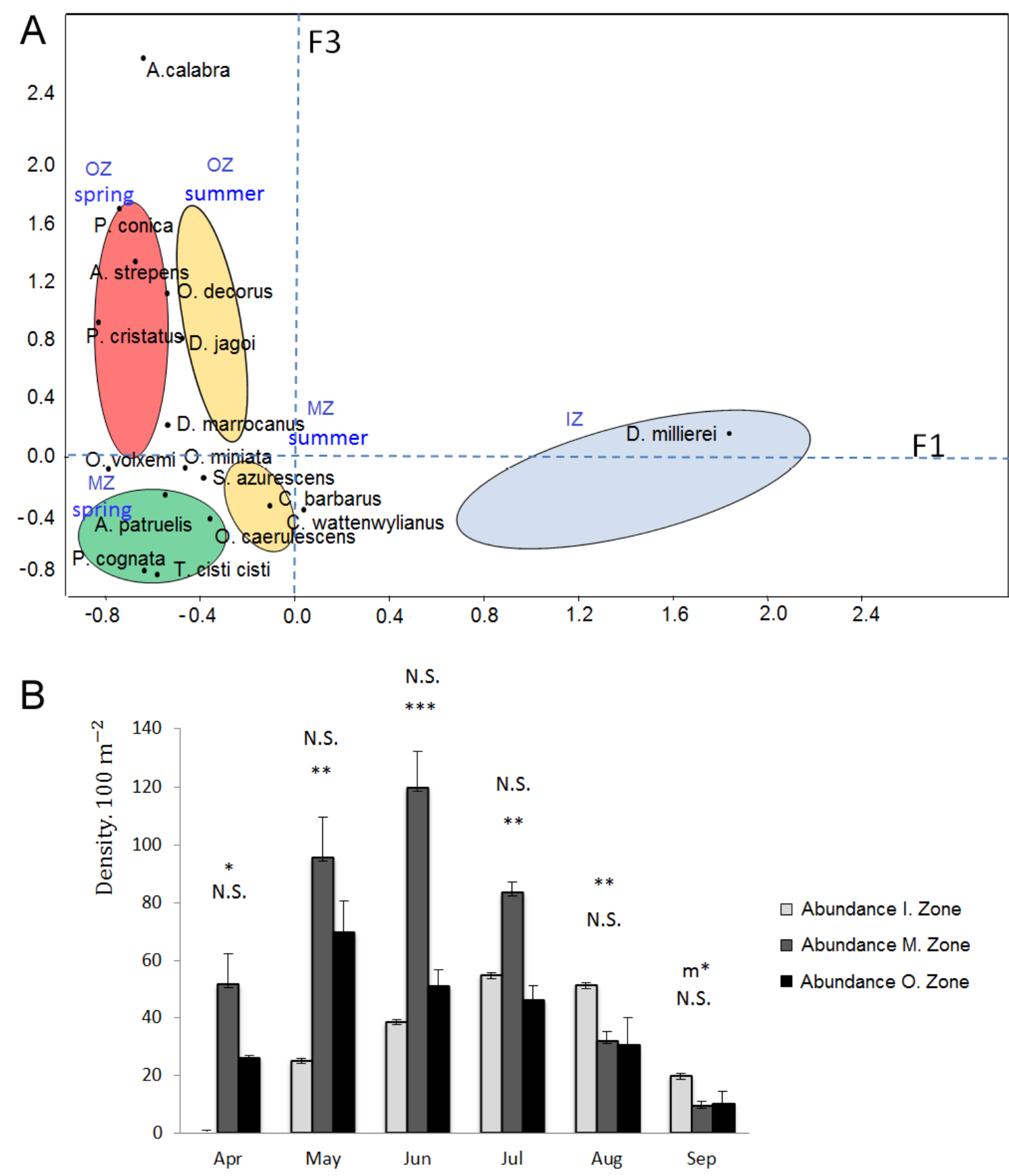

Fig. 5. Assemblage analysis of grasshoppers. A - correspondence analysis (CA) of grasshopper populations. The five assemblages revealed by a cluster analysis using the 3 first scores of the CA and Euclidean distance. B - numbers of grasshoppers per unit area recorded in the three zones (based on 4 measures per month and per zone). Lower significances: differences in numbers per unit area; upper significances: differences in numbers per unit area after removal of richness. Abbreviations: ${ }^{*} p<0.05 ;{ }^{* *} P<0.01 ;{ }^{* * \star} p<0.001$.

density, Dominance D, and Shannon index H') and significantly higher density and diversity (indicated by H') in the middle zone than in the outer zone. The ANOSIM (Bray-

Table 2. Parameters of grasshopper assemblages recorded in each zone. The different letters correspond to significant differences (permutation test).

\begin{tabular}{lccc}
\hline & Inner zone & Middle zone & Outer zone \\
\hline Taxa_S & $3 a$ & $14 \mathrm{~b}$ & $15 \mathrm{~b}$ \\
Sample rarefaction & 3 & 14 & 15 \\
Mean density / $100 \mathrm{~m}^{2}$ & $32.50 \mathrm{a}$ & $66.58 \mathrm{~b}$ & $38.87 \mathrm{c}$ \\
Dominance D & $0.65 \mathrm{a}$ & $0.12 \mathrm{~b}$ & $0.11 \mathrm{~b}$ \\
Shannon H' & $0.66 \mathrm{a}$ & $2.28 \mathrm{~b}$ & $2.43 \mathrm{c}$ \\
\hline
\end{tabular}

Curtis as distance measure, 10,000 permutations) revealed that the compositions of grasshopper assemblages in the three zones differed significantly $(\mathrm{p} \leq 0.01)$.

Taking into consideration both month and zone as factors, we determined whether the assemblages defined above could be split into sub-groups. A Correspondence Analysis followed by a Cluster Analysis of the scores on the three first axes revealed five well separated assemblages (Fig. 5A). The first is that recorded in the inner zone with Dericorys millierei the characteristic species. Distinct spring and summer assemblages were recorded in the middle and outer zones. The lists of the species in each of 

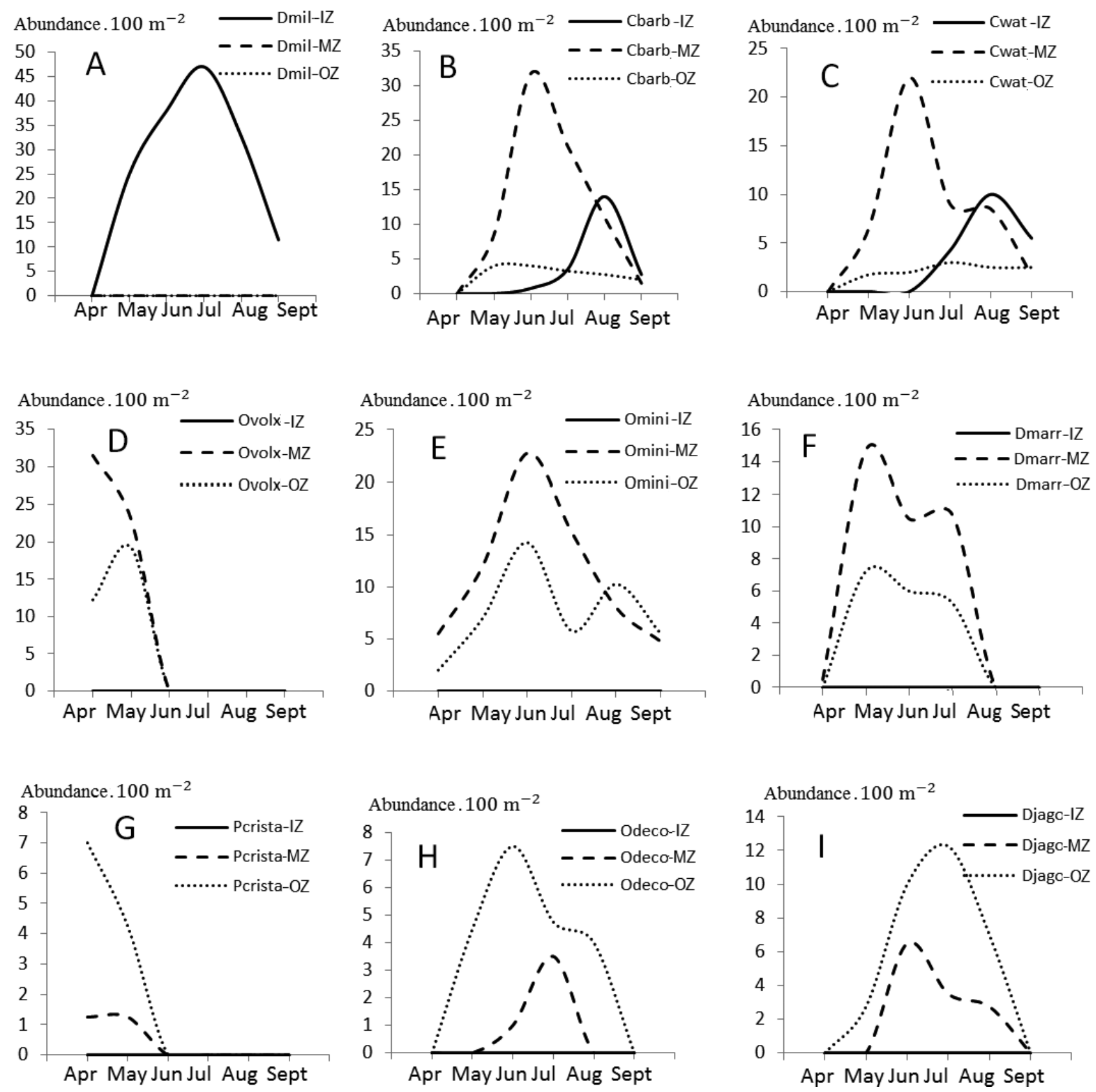

Fig. 6. Monthly numbers of dominant species of grasshoppers recorded per unit area in the three zones. Abbreviations: Dmil - Dericorys millierei; Cbarb - Calliptamus barbarus; Cwat - Calliptamus wattenwylianus; Ovolx - Ocneridia volxemii; Omini - Oedipoda miniata; Dmar - Dociostaurus maroccanus; Pcrista - Pamphagus cristatus; Odeco - Oedaleus decorus; Djago - Dociostaurus jagoi.

Table 3. The five acridian assemblages according to zone and season.

\begin{tabular}{|c|c|c|c|c|}
\hline \multirow[b]{2}{*}{ Inner zone } & \multicolumn{2}{|c|}{ Spring } & \multicolumn{2}{|c|}{ Summer-Autumn } \\
\hline & \multicolumn{4}{|c|}{ Dericorys millierei: Sub-monophagous on Amaranthaceae } \\
\hline \multirow{6}{*}{ Middle zone } & & & Oedipoda caerulescens & Forbivore 5,7 \\
\hline & Tmethis cisti & Ambivore $^{2}$ & Oedipoda miniata & Oligophage $^{1}$ \\
\hline & Ocneridia volxemii & Ambivore ${ }^{6}$ & Sphingonotus azurescens & Oligophage $^{1}$ \\
\hline & Pyrgomorpha cognata & $?$ & Calliptamus barbarus & Ambivore ${ }^{1}$ \\
\hline & \multirow{2}{*}{ Acrotylus patruelis } & \multirow{2}{*}{ Ambivore $^{7}$} & Dociostaurus maroccanus & Ambivore $^{1}$ \\
\hline & & & Calliptamus wattenwylianus & $?$ \\
\hline \multirow{3}{*}{ Outer zone } & Aiolopus strepens & Ambivore $^{4}$ & Dociostaurus jagoi & Ambivore $^{3}$ \\
\hline & Pyrgomorpha conica & Forbivore $^{7}$ & Oedaleus decorus & Oligophage $^{1}$ \\
\hline & Pamphagus cristatus & Ambivore $^{2}$ & & \\
\hline
\end{tabular}

1 Zaim et al. (2013); ${ }^{2}$ Benkenana et al. (2012); ${ }^{3}$ Moussi et al. (2014); ${ }^{4}$ Bonnet (1997); ${ }^{5}$ Savitsky (2010); ${ }^{6}$ Bounechada \& Doumandji (2011); ${ }^{7}$ Gangwere \& Morales-Agacino (1973). 

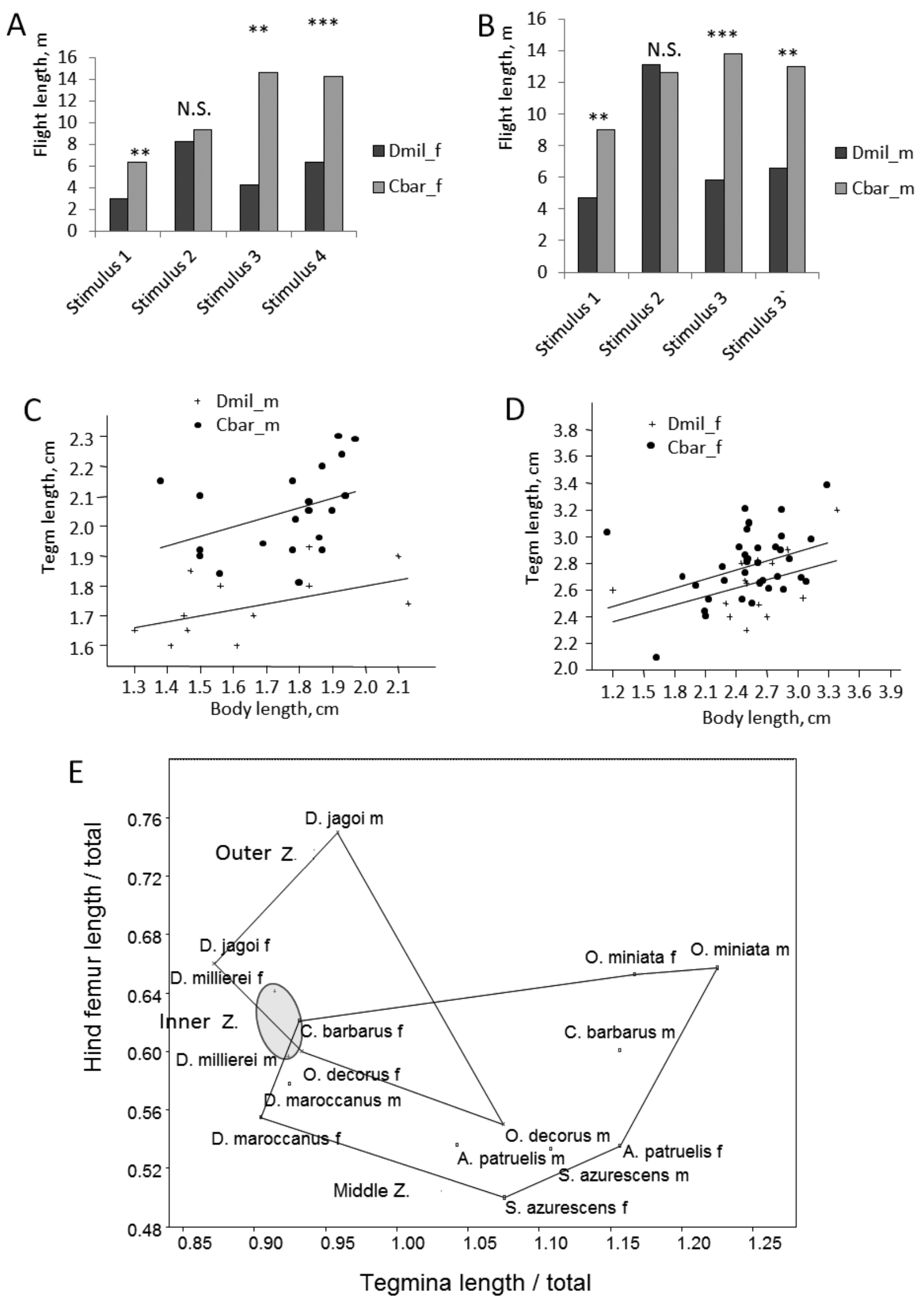

Fig. 7. Dispersal abilities of Dericorys millierei and Calliptamus barbarus. Flight length of males (A) and females (B) of both species (recorded for 10 males and 10 females of each species). ANCOVA of tegmen length relative to total length for males (C) and females (D) of both species (35 males and 50 females). $\mathrm{E}$ - relative femur length over relative tegmina length of the grasshoppers of the three zones. Abbreviations: ${ }^{*} \mathrm{p}<0.05 ;{ }^{* *} \mathrm{P}<0.01 ;{ }^{* * *} \mathrm{p}<0.001$. 


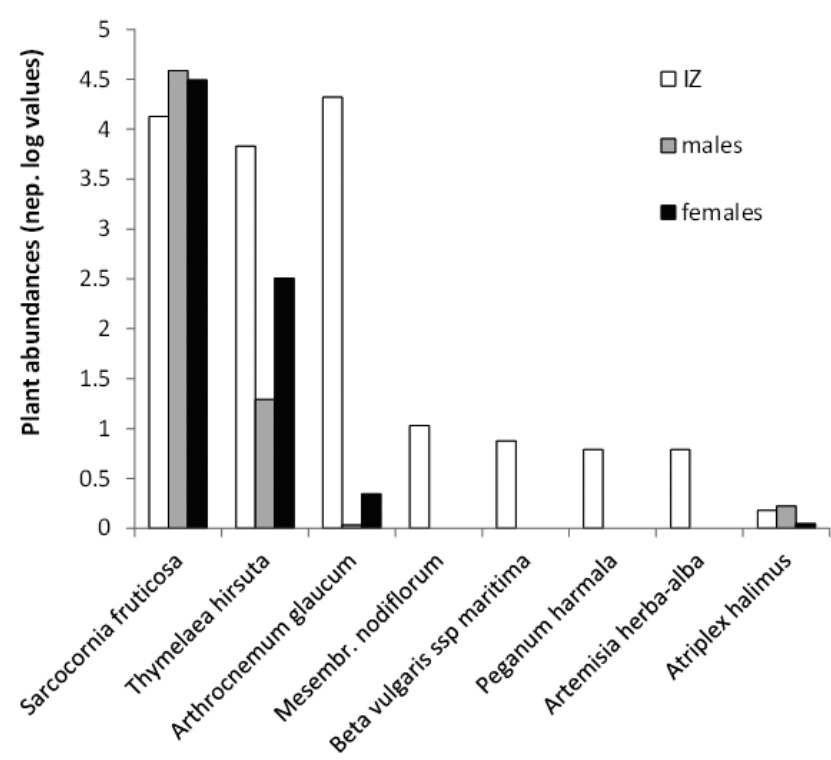

Fig. 8. Diet of Dericorys millierei collected in the inner zone. The histogram shows the log-transformed values of the abundance of particular species of plants in the inner zone and of the surface area (in $\mathrm{mm}^{2}$ ) of the microscope slide covered fragments of those plants.

the assemblages are in Table 3. To verify that the species compositions of the assemblages differed significantly, an ANOSIM (Bray-Curtis as an index of distance, 10,000 permutations) with two factors, the seasons (spring versus summer-autumn) and zones, was used. The result revealed significant differences in the composition in terms of both factors $(\mathrm{p}<1 \% \mathrm{c})$.

The comparison of the abundances in the different months and zones (Fig. 5B) revealed that the maximum abundances were recorded in the middle zone in June with approximately 120 individuals per $100 \mathrm{~m}^{2}$, whereas in the outer zone the greatest abundances were recorded in May. In the inner zone, the first adults were recorded at the beginning of May after which the numbers increased gradually and peaked in August. There were significant differences in abundances in the three zones in May $(p=0.003)$, June $(p=0.0001)$ and July $(p=0.002)$, but the difference in September was only marginally significant $(p=0.083)$. If the species richness in each zone is not taken into consideration (inner zone $r=0.066$; middle zone $r=9.710^{-10}$; outer zone $r=1.110^{-9}$ ), however, the ANOVAs of the residuals reveal significant differences in the abundances in the different zones in August and September $(\mathrm{p}<0.01)$.

\section{Grasshopper phenology}

During this study, the occurrence of grasshopper instars differed for the different species with those of the Pamphagidae the first to appear at the beginning of April, followed by the Oedipodinae and Gomphocerinae. Calliptamus barbarus, C. wattenwylianus Pantel, 1896 and Dericorys millierei appeared in late May-early June, in the middle zone in the case of Calliptamus spp and in the inner zone in the case of $D$. millierei.

To determine the temporal changes in abundance of adult grasshoppers in the different zones, we concentrated on the most characteristic species in each zone (Fig. 6). This fig- ure shows the exclusive presence of Dericorys millierei in the inner zone. However, the maximum abundance of the Calliptaminae was recorded in the middle zone except in August and September, when they were mostly recorded in the inner zone (Fig. 6B, C).

The Pamphagidae, Ocneridia volxemii (Bolívar, 1878) and Pamphagus cristatus Descamps \& Mounassif, 1972 were present only during the spring and mainly in the middle zone in the case of Ocneridia volxemii (Fig. 6D) and the outer zone for Pamphagus cristatus (Fig. 6G). The Oedipodinae, Oedipoda miniata and Oedaleus decorus (Germar, 1825) were most abundant in the middle zone (Fig. 6E) and the outer zone (Fig. 6H), respectively, as were the Gomphocerinae, Dociostaurus maroccanus (Thunberg, 1815) (Fig. 6F) and Dociostaurus jagoi Soltani, 1978 (Fig. 6I).

\section{Dispersal}

To understand the temporal changes in distribution we focused our studies on two species, Dericorys millierei a characteristic of the inner zone and Calliptamus barbarus, which moves from the middle zone to the inner zone at the end of summer. Based on these observations, it was predicted that the flight activity $C$. barbarus would be more marked than that of $D$. millierei.

By subjecting males and females of both species to a succession of simulated attempts at capturing them, we determined whether their flight activity differed significantly. The ANOVAs revealed that in the first flying jumps, Calliptamus barbarus of both sexes flew further than Dericorys millierei. In a response to the second stimulus both species flew the same distance but further than previously (7A, 7B). In subsequent stimulations, males and females of Calliptamus barbarus flew further than Dericorys millierei, which tended to seek refuge in the centre of dwarf bushes.

Based on the above the expectation was that the relative length of the tegmina (fore wings) over body length is greater in Calliptamus barbarus than in Dericorys millierei. ANCOVAs of tegmina length with body length as a covariate, indicated that the wings of male $C$. barbarus are clearly relatively longer than those of $D$. millierei $(\mathrm{p}=$ $5.1910^{-7}, \mathrm{~N}=35$, Fig. 7C), but for females there was no significant difference ( $p=0.059, \mathrm{~N}=50$, Fig. 7D). To illustrate this idea, we plotted (Fig. 7E) the ratios of tegmen length and hind femur length over total length of the most frequent species in the three zones. We excluded wingless species because they have maximized egg production by investing less in flight ability. The MANOVAs of the 2 ratios indicated a significant difference between middle and outer zone grasshoppers (Hotelling's $p=0.012$ ) but none between other zone combinations. The centroid of outer zone grasshoppers is displaced more towards relatively longer hind femurs and shorter tegmina than the middle zone grasshoppers.

\section{Diet}

For D. millierei the percentage of their diet made up of each species of plant reflects the abundance of these plants in the inner zone. Indeed, the Pearson correlation with log- 
transformed values of plant abundances is significant ( $p$ $\leq 0.1 \%$ ). Of the four plant species consumed, grasshoppers fed primarily on Amaranthaceae (around 72\%) and Thymelaeaceae (28\%) (Fig. 8). It is striking that some abundant plants in the inner zone were not eaten, such as Mesembryanthemum nodiflorum, Beta vulgaris ssp. maritima, Peganum harmala and Artemisia herba-alba.

The diet of Calliptamus barbarus was much more diverse as pieces of 22 species of plants were identified in their faeces. The most frequently consumed families were Asteraceae (7 species), Poaceae (6 species) and Plantaginaceae (3 species). If we compare the plants consumed to their abundances in the field (log-transformed values), there was a significant correlation with the abundance of the plants in the middle zone $(\mathrm{p}=0.044)$.

\section{DISCUSSION}

Our analyses show a marked difference between the inner and the two outer zones, in terms of their plant associations and grasshopper assemblages. The inner zone contains only halophytes and salt tolerant plants, whereas the outer zones are colonized by steppe land and fallow land species. As the chloride content of the soil is higher in the inner than in outer zones, whereas the concentration of sulphate ion is similar, it is concluded that the different vegetation types are determined mainly by the concentration of chlorides. If the concentrations of all the different exchangeable ions measured are considered, the soil is of intermediate salinity, except in July and August in the inner zone when it is highly saline (Brouwer et al., 1985).

In both the middle and outer zones there were steppe plants, as defined by Le Houérou et al. (1977), mainly $A r$ temisia herba-alba, Astragalus armatus ssp. armatus, Lygeum spartum and Hertia cheirifolia, which made up only $2.5 \%$ of vegetation cover in the middle zone and $6.5 \%$ in the outer zone. This indicates anthropic disturbance in the middle and outer zones. In addition, in these two zones there are wasteland species of plants and crop weeds suggesting that these two zones were cultivated in the past. Indeed, on rare occasions we recorded individual wheat plants, which indicates the nature of these ancient crops, and wheat is still commonly cultivated around the chotts in this area (Boumezbeur \& Khalfallah, 2005). In terms of the fallow-land species, there was a greater proportion of therophytes in the outer zone and of perennial species in the middle zone. This indicates that the outer zone was more recently cultivated than the middle zone. In addition, as a result of regular grazing by sheep flocks, the soil was devoid of plants in many places, which favours the growth of annual Mediterranean pioneer plant species.

The plant species composition of the vegetation in the three zones, conditions, abundance and species composition of grasshopper assemblages were recorded. As mentioned earlier, no plants of the family Poaceae were recorded in the inner zone. In contrast, there are seven species of this plant family in both the middle and outer zones. Given the importance of Poaceae as food for grasshoppers (Uvarov, 1977), it accounts for the richer diversity grass- hoppers in these zones, with 15 species of grasshoppers in both the middle and outer zones. It is noteworthy, that annual plants make up $66 \%$ of the vegetation in the middle zone and $70 \%$ in the outer zone. As these plants dry out in early summer, this could account for the temporal succession of the two faunas, one in spring and the other in summer-autumn.

The species that develop early, especially those of the family Pamphagidae feed on annual species (Benkenana et al., 2013). This is in marked contrast to the species that develop later, the Oedipodinae (Oedaleus decorus, Oedipoda miniata) and Gomphocerinae (Dociostaurus jagoi). The temporal variations in the distributions of the grasshoppers indicate that only the Calliptaminae moved between zones. This behaviour is associated with polyphagy, as the analysis of the faeces of these species revealed they fed on wide variety of plants in May and June. We did not study their diet in late summer when they moved towards the inner zone, but Calliptamus barbarus feeds on Sarcocornia fruticosa and Halocnemum strobilaceum at chott Ezzmoul, which is only a few kilometers from chott Tinsilt (Benkenana \& Harrat, 2007). Thus, the summer movement of Calliptaminae is to find the fresh plants they need. In contrast, the other species of grasshoppers did not feed on halophilic plants and stayed in the same zone. Analysis of literature (see legend of Table 3 ) indicates that several species of grasshoppers have diverse diets (grasses and dicotyledonous plants), e.g., C. barbarus, that is they are ambivores. Unlike $C$. barbarus, there are species that remain in the same zone, but this behaviour is not associated with the availability of food as there are edible species of plants in both zones. One can invoke the weak dispersal ability of the wingless species of Pamphagidae, O. volxemii, P. cristatus and $A$. calabra or a preference for a particular density of vegetation, as the vegetation in outer zone is denser than in the middle zone. The hind femurs of grasshoppers in the outer zone are relatively more developed than those in the middle zone (ratios over total body length around 0.75 and 0.60 , respectively). This indicates that the grasshoppers of the outer zone are better at walking, which could be advantageous for colonizing areas recently abandoned.

There is only one species strictly associated with the inner zone, namely Dericorys millierei (Dericorythidae). Two factors determine the strong association between this species and the vegetation in the inner zone. First, faeces of D. millierei contained only plant debris of Amaranthaceae and Thymelaeaceae. This is similar to that recorded for other species of the genus Dericorys. Savitsky (2010) reports that Dericorys tibialis (Pallas, 1773) consumes Anabasis aphylla, Caroxylon orientale, and Salsola incanescens and Gangwere et al. (1998) that the diet of D. lobata lobata (Brullé, 1840) is mainly composed of Amaranthaceae in the Canary Islands. This is similar to that reported for another genus of the same family, e.g. Pamphagulus: P. bodenheimeri dumonti (Uvarov, 1929) and P. uvarovi (Ramme, 1931), feed on Amaranthaceae in the steppe and the palm oasis of Biskra (Moussi et al., 2014). This indicates that species of the family Dericorythidae are almost 
monophagous in feeding mainly on Amaranthaceae. This hypothesis needs to be tested by studying other genera. This ability to consume halophilic plants is very rare and only recorded in Western Europe for Epacromius tergestinus tergestinus (Charpentier, 1825) (Jourde et al., 1995). It is likely that Tropidopola cylindrica (Marschall, 1836) also belongs to this category as it feeds on Phragmites australis (Gangwere \& Spiller, 1995) growing in salt humid environments (Benkenana, pers. comm.). Second, bushy halophyte plants serve as a refuge for males and females of $D$. millierei. We have shown that when disturbed, they escape by jumping into the center of these plants, as previously reported by Moussi et al. (2014) for Pamphagulus spp. at Biskra. The use of bushes of plants of Amaranthaceae as sources of food and refuges may account for $D$. millierei on branches of Anabasis, Zygophyllum and Atriplex and D. albidula Serville, 1838 on halophilic vegetation near the Dead Sea in Palestine (Fishelson, 1985) and on Haloxylon in central Asia (Bei-Bienko \& Mishchenko, 1963). The avoidance of Mesembryanthemum nodiflorum and Peganum harmala could be due their toxicity as demonstrated by Jacob \& Peet (1989) and Hassani \& Hermas (2008).

Grasshoppers are important species in food chains due to their limited and daily activity, ease of capture and richness in protein (Blásquez et al., 2012). They are an attractive prey for birds in the breeding season. We observed Cattle Egret (Bubulcus ibis) in the inner zone and White Stork (Ciconia ciconia L.) in both the inner and middle zones, both of which feed on insects, particularly grasshoppers, which make up $50 \%-60 \%$ of the insects they consume ( $\mathrm{Si}$ Bashir et al., 2001; Boukhemza et al., 2004). We also found another insectivorous bird nesting in the middle zone, the Eurasian skylark (Alauda arvensis L., 1758). Furthermore Chenchouni (2010) reports the presence of Neophron percnopterus (L.) 1758 in this chott, where it occasionally consumes insects, this bird being mainly a scavenger. Its presence in August coincides with when grasshoppers are most abundant on the salt-tolerant shrubs. Although this bird list is less from exhaustive, it illustrates the high potential of the inner and middle zones as sources of food for birds, the middle zone from April to July and the inner zone from July, although the abundance there was low.

The main threat to the salt lake complex on the Constantine plateau is not of climatic origin, although this area was classified as semi-arid in 1946 and arid in 1990, but human populations that have used the resources of this area for centuries. There has been a recent increase in the rural population, more pronounced on the steppes than in the rest of Algeria (Nedjraoui \& Bédrani, 2008). Between 1968 and 2006, the livestock on Algerian steppes increased from $610^{6}$ to $1910^{6}$ animals (Kanoun et al., 2007). The human effect around wetlands has dramatically worsened due to poaching, water abstraction and pollution. These factors together have resulted in the virtual elimination of vegetation in the humid areas, severe erosion and poor regeneration (Medail \& Quézel, 1999; Green et al., 2002). The areas between the chotts are used for growing crops that replace the indigenous flora (Boumezbeur \& Khalfallah, 2005), creating ecological islands.

In conclusion, the immediate environment around the chotts and the spaces between them are severely affected by human activity, which has reduced the number of species, their distribution and abundance, structure of the communities and productivity, and overall biodiversity. The different organisms respond differently due to differences in their ability to disperse. The most remarkable grasshopper in this area, D. millierei, is dependent on bushes of Amaranthaceae, a strategy that is highly risky if the risk of perturbations that destroy these plants is high. This is partly counterbalanced by their ability to move out of the area by means of long-distance flights. In the chott complex on the high plateau of Constantine, the different chotts are not more than $30 \mathrm{~km}$ apart. But a step by step movement is only possible if the grasshoppers find suitable bushes between neighbouring chotts. The increase in the area covered by crops in recent years has resulted in the destruction of Amaranthaceae bushes, which makes it difficult for D. millierei to escape from its native chott.

ACKNOWLEDGEMENTS. We thank A. Blondeau-DaSilva for her helpful comments on the draft manuscript and F. Vallet for her technical assistance.

\section{REFERENCES}

Bagnouls F. \& Gaussen H. 1953: Saison sèche et indice xérothermique. - Bull. Soc. Hist. Nat. Toulouse 88: 193-240.

Bei-Bienko G. \& Mishchenko L. 1963: Locusts and Grasshoppers of the USSR and Adjacent Countries. Part I. Israel Program for Scientific Translation, Jerusalem, $400 \mathrm{pp}$.

Benfekih L. \& Petit D. 2010: The annual cycle of Saharan populations of Locusta migratoria cinerascens (Orthoptera: Acrididae: Oedipodinae) in Algeria. - Ann. Soc. Entomil. Fr. 46: 351-358.

Ben Halima T.B., Gillon Y. \& Louveaux A. 1984: Utilisation des ressources trophiques par Dociostaurus maroccanus (Thunberg, 1815) (Orthopt.: Acrididae): choix des espèces consommées en fonction de leur valeur nutritive. - Acta Oecol. 5: 383-406.

Ben Halima T.B., Gillon Y. \& Louveaux A. 1985: Spécialisation trophique individuelle dans une population de Dociostaurus maroccanus (Orthopt.: Acrididae). - Acta Oecol. 6: 17-24.

Benkenana N. \& Harrat A. 2007: Contribution à l'inventaire de la faune acridienne dans la région de Aïn-Mlila (Sebkha) et régime alimentaire de Calliptamus barbarus (Costa, 1836) et Ochrilidia geniculata (I. Bolivar, 1918). In: Actes des Journées Internationales sur la Zoologie Agricole et Forestières, Institut National Agronomique (I.N.A.), El-Harrach, Alger, 8 Avril 2007.

Benkenana N., Harrat A. \& Petit D. 2012: The Pamphagidae (Orthoptera) from East Algeria and description of a new species. - Zootaxa 3168: 22-38.

Benkenana N., Harrat A. \& Petit D. 2013: Analysis of the number of sensilla on the labrum and the diet of grasshoppers belonging to the family Pamphagidae (Orthoptera). - Eur. J. Entomol. 110: 355-364.

Blásquez J.R.E., Moreno J.M.P. \& CAMACho V.H.M. 2012: Could grasshoppers be a nutritive meal? - Food Nutr. Sci. 3: 164-175. 
Bonnet E. 1997: Phylogénie et partage des ressources chez les Orthoptères Acridiens. PhD Thesis, Université de Limoges, $160 \mathrm{pp}$.

Boukhemza M., Doumandis S., Voisin C. \& Voisin J.F. 2004: Comparative utilization pattern of trophic resources by White storks Ciconia ciconia and Cattle egrets Bubulcus ibis in Kabylia (Algeria). - Terre et Vie (Rev. Ecol.) 59: 559-580.

Boumezbeur A. \& Khalfallah Y. 2005: Fiche descriptive sur les zones humides Ramsar chott Tinsilt (Wilaya d'Oum El Bouaghi). Rapport direction générale des forêts. Ministère de l'Agriculture et du Développement Rural, Algérie, 9 pp.

Bounechada M. \& DoumandJI S. 2011: Régime alimentaire et évolution de la consommation des feuilles de blé dur (Triticum durum) chez Ocneridia volxemii (Insecta, Orthoptera) dans la région de Sétif. - Agriculture 2: 33-42.

Britton R.H. \& CRivelli A.J. 1993: Wetlands of southern Europe and North Africa: Mediterranean wetlands. In Whigham D.F., Dykyjová D. \& Hejný S. (eds): Wetlands of the World: Inventory, Ecology and Management. Vol. 1. Kluwer, Dordrecht, pp. 129-194.

Brouwer C., Goffeau A. \& Heibloem M. 1985: Irrigation Water Management: Training Manual No. 1 - Introduction to Irrigation. Food and Agriculture Organization of the United Nations, Rome, $152 \mathrm{pp}$.

Chenchouni H. 2010: Statuts de protection et de conservation des oiseaux recensés dans les Aurès et ses alentours (nord-est Algérien). Actes du Séminaire International sur la Biodiversité Faunistique en Zones Arides et Semi-arides, Ouargla University, Algeria, pp. 56-75.

Chopard L. 1943: Orthoptéroides de l'Afrique du Nord. Librairie Larose, Paris, $450 \mathrm{pp}$.

Clarke K.R. 1993: Non-parametric multivariate analysis of changes in community structure. - Austr. J. Ecol. 18: 117-143.

Eades D.C., Otte D., Cigliano M.M. \& Braun H. 2013: OSF2. Version 2.0/4.1. URL: http://Orthoptera.SpeciesFile.org.

Fishelson L. 1985: Fauna Palaestina: Insecta III. Orthoptera: Acridoidea. The Israel Academy of Sciences and Humanities, Jerusalem, $229 \mathrm{pp}$.

Gangwere S.K. \& Morales-Agacino E. 1973: Food selection and feeding behavior in Iberian Orthopteroidea (1) (2). - An. Inst. Nac. Invest. Tecn. Agr. Alim. (Prot. Veg.) 3: 251-337.

Gangwere S.K. \& Spiller D.O. 1995: Food selection and feeding behavior in selected Orthoptera sen. lat. of the Balearic Islands, Spain. - J. Orthopt. Res. 4: 147-160.

Gangwere S.K., McKinney J.C., Ernemann M.A. \& Bland R.G. 1998: Food selection and feeding behavior in selected Acridoidea (Insecta: Orthoptera) of the Canary Islands, Spain. $-J$. Orthopt. Res. 7: 1-21.

Gardiner T., Hill J. \& Chesmore D. 2005: Review of the methods frequently used to estimate the abundance of Orthoptera in grassland ecosystems. - J. Insect Conserv. 9: 151-173.

Green A.J., Hamzaoui M.E., ElAgbani M.A. \& Franchimont J. 2002: The conservation status of Moroccan wetlands with particular reference to waterbirds and to changes since 1978 . Biol. Conserv. 104: 71-82.

Guendouz-Benrima A., Doumandj Mitiche B. \& Petit D. 2011: Effects of weak climatic variations on assemblages and life cycles of Orthoptera in North Algeria. - J. Arid Envir. 75: 416-423.

Guido M. \& Gianelle D. 2001: Distribution patterns of four Orthoptera species in relation to microhabitat heterogeneity in an ecotonal area. - Acta Oecol. 22: 175-185.

Hammer D.A.T., Harper P.D. \& RyAN P. 2001: PAST: Paleontological statistics software package for education and data analysis. - Palaeont. Electr. 4(1) 9 pp.
Hassani L.I. \& Hermas J. 2008: Effets de l'alimentation en Peganum harmala L. (Zygophyllaceae) sur le tube digestif du criquet pèlerin Schistocerca gregaria Forsk. (Orthoptera, Acrididae). - Zool. Baetica 19: 71-84.

Houhamdi M., Maazi M.C., Seddik S., Bouaguel L., Bougoudil S. \& SAHEB M. 2009: Statut et écologie de l'Érismature à tête blanche (Oxyura leucocephala) dans les hauts plateaux de l'Est de l'Algérie. - Aves 46: 9-19.

JACOB R.H. \& PEeT R.L. 1989: Acute oxalate toxicity of sheep associated with slender iceplant (Mesembryanthemum nodiflorum). - Austr. Vet. J. 66: 91-92.

JigUeT F. 2002: Arthropods in diet of Little Bustards Tetrax tetrax during the breeding season in western France: Seasonal, age-and sex-related variations in the diet were studied during March to October. - Bird Study 49: 105-109.

Jourde P., Sardet E., Perru S. \& Barataud J. 2005: Contribution à la connaissance de la répartition de l'Oedipode des salines Epacromius tergestinus tergestinus (Charpentier, 1825) en Charente-Maritime (Orthoptera, Caelifera). - Ann. Soc. Sci. Nat. Charente-Maritime 9: 523-528.

JuLVE P. 1998: ff. Baseveg. Index phytosociologique synonymique de la végétation de la France. Version 20th of August, 2010. Programme Catminat. URL: http://perso.wanadoo.fr/philippe. julve/catminat.htm.

KaAbeche M. 1996: La végétation steppique du Maghreb (Algérie, Maroc, Tunisie). Essai de synthèse phytosociologique par application des techniques numériques d'analyse. - Doc. Phytosoc. N.S. (Camerino) 16: 45-58.

Kanoun A., Kanoun M., Yakhlef H. \& Cherfaoui M.A. 2007: Pastoralisme en Algérie: Systèmes d'élevage et stratégies d'adaptation des éleveurs ovins. - Renc. Rech. Ruminants 14: 181-184.

Le HouÉRou H.N. 2001: Biogeography of the arid steppeland north of the Sahara. - J. Arid Envir. 48: 103-128.

Le Houérou H.N., Claudin J., Pouget M. \& Amrani D. 1977: Etude bioclimatique des steppes algériennes (avec une carte bioclimatique à $1 / 1000000$ ème). - Bull. Soc. Hist. Nat. Afr. Nord 68: 33-74.

Louveaux A., Amedegnato C., Poulain S. \& Desutter-GrandcoLAS L. 2013: Acridomorpha de l'Afrique du Nord-Ouest. URL: http://acrinwafrica.mnhn.fr.

Massa B. 1978: Observations on Eleonora's falcon Falco eleonorae in Sicily and surrounding islets. - Ibis 120: 531-534.

Massa B. 2013: Pamphagidae (Orthoptera: Caelifera) of North Africa: key to genera and the annotated check-list of species. - Zootaxa 3700: 435-475.

Mathieu C. \& Pieltain F. 2003: Chemical Soil Analysis: Chosen Methods. Lavoisier, Paris, 408 pp.

MéDAIL F. \& QuÉZel P. 1999: Biodiversity hotspots in the Mediterranean Basin: setting global conservation priorities. - Conserv. Biol. 13: 1510-1513.

Mokhlesse R., Lazraq A., Azouzid A., Petit D. \& ElGhadraoui L. 2007: Etude des capacités des déplacements des acridiens à Al-Azaghar (Moyen Atlas, Maroc). — Bull. Inst. Sci. Rabat (Sci. Vie) 29: 21-26.

Moussi A., Abba A., Harrat A. \& Petit D. 2011: Desert acridian fauna (Orthoptera, Acridomorpha): comparison between steppic and oasian habitats in Algeria. - C. R. Biol. 334: 158-167.

Moussi A., AbBa A., Harrat A. \& Petit D. 2014: Description of Dociostaurus biskrensis sp. nov. and male allotypes of four species: Pamphagulus bodenheimeri dumonti, P. uvarovi, Sphingonotus ebneri and Notopleura pygmaea (Orthoptera: Acridoidea) in the region of Biskra, Algeria. - Zootaxa 3755: 379-390. 
NedjRaoui D. \& Bédrani S. 2008: La désertification dans les steppes algériennes: causes, impacts et actions de lutte. - VertigO 8(1). URL: http://vertigo.revues.org/5375; doi: 10.4000/ vertigo. 5375 .

Ould El Hadj M. 2004: Le problème acridien au Sahara algérien. $\mathrm{PhD}$ Thesis, Institut National Agronomique El Harrach, Alger, $85 \mathrm{pp}$.

Pantone N., Bux M. \& Scillitani G. 1999: Dieta del Grillaio Falco naumanni nell'Italia Peninsulare. - Avocetta 23: 171.

Penman H.L. 1948: Natural evaporation from open water, bare soil and grass. - Proc. R. Soc. Lond. 193: 120-145.

Pennings S.C., Grant M.B. \& Bertness M.D. 2005: Plant zonation in low latitude salt marshes: disentangling the roles of flooding, salinity and competition. - J. Ecol. 93: 159-167.

Petrt D. 2014: Climatic changes in Algeria and responses from acridian insects. - Agrobiologia 6: 5-12.

Picaud F. \& Petit D.P. 2007: Primary succession of Acrididae (Orthoptera): Differences in displacement capacities in early and late colonizers of new habitats. - Acta Oecol. 32: 59-66.

Poole R.W. 1974: An Introduction to Quantitative Ecology. McGraw-Hill, New York, 480 pp.

QuÉzel P. \& SANTA S. 1962-1963 : Nouvelle flore de l'Algérie et des régions désertiques méridionales. CNRS, Paris, 566 pp.

SAVITSKY V.Y. 2010: Trophic relationships and their importance for biotopic distribution of grasshoppers (Orthoptera, Acridoidea) in semi-deserts and deserts of the lower Volga river area. - Entomol. Rev. 90: 830-856.

Seltzer P. 1946: Le climat de l'Algérie. Vol. 1. Carbonel, Alger, $312 \mathrm{pp}$.

Si Bachir A., Hafner H., Toureng J.N., DoumandjI S. \& Lek S 2001: Diet of adult cattle egrets (Bubulcus ibis) in a new North African colony (Soummam, Kabylie, Algeria): taxonomic composition and seasonal variability. - Ardeola 48: 217-223.

Sobhi Z., Allal-Benfekih L. \& Petit D. 2013: Biodiversité acridienne des zones humides et des écosystèmes forestiers (de Quercus suber et de Q. canariensis): Effets du climat et de la végétation. - Bull. Soc. Zool. Fr. 138: 229-250.

Souttou K., Baziz B., Doumandu S., Denys C. \& Brahimi R. 2007: Prey selection in the common kestrel, Falco tinnunculus (Aves, Falconidae) in the Algiers suburbs (Algeria). — Folia Zool. (Praha) 56: 405-415.

Thornthwaite C.W. 1948: An approach toward a rational classification of climates. - Geogr. Rev. 38: 55-94.

Uvarov B. 1977: Grasshoppers and Locusts. A Handbook of General Acridology. Vol. 2. Behaviour, Ecology, Biogeography, Population Dynamics. Centre for Overseas Pest Research, Cambridge University Press, 613 pp.

Zaim A., Petit D. \& ElGhadraoui L. 2013: Dietary diversification and variations in the number of labrum sensilla in grasshoppers: Which came first? — J. Biosci. 38: 339-349.

Received July 18, 2015; revised and accepted November 27, 2015 Published online February 5, 2016
Appendix 1. The months considered as dry are on grey background.

\begin{tabular}{lcc}
\hline Months & Aridity index 2014 & Aridity index 2000 \\
\hline January & 2.608 & 4.689 \\
February & 2.357 & 1.965 \\
March & 1.304 & 1.560 \\
April & 0.711 & 0.691 \\
May & 0.460 & 0.489 \\
June & 0.125 & 0.204 \\
July & 0.047 & 0.040 \\
August & 0.112 & 0.104 \\
September & 0.385 & 0.391 \\
October & 0.375 & 0.466 \\
November & 1.197 & 0.969 \\
December & 3.482 & 3.765 \\
\hline
\end{tabular}


Appendix 2. Plants recorded in the three zones of Chott Tinsilt. The abundances for each species and each zone are the counting means along the $10 \mathrm{~m}$ long rope (five repetitions).

\begin{tabular}{llll}
\hline Family & Species & IZ MZ OZ & Phytosociological classes
\end{tabular}

\begin{tabular}{lcccccc}
\hline AMARANTHACEAE & Sarcocornia fruticosa (L.) AJ Scott & 61 & 0 & 0 & $\begin{array}{c}\text { Sarcocornietea fruticosae Braun-Blanquet \& Tüxen, 1943 } \\
\text { ex A. \& O. de Bolòs in A. de Bolòs, 1950 }\end{array}$ \\
\hline THYMELAEACEAE & Thymelaea hirsuta (L.) Endl. & 45 & 0 & 0 & Pegano harmalae - Salsoletea vermiculatae Braun-Blanquet \& O. de Bolòs, 1958 \\
\hline AMARANTHACEAE & $\begin{array}{c}\text { Arthrocnemum macrostachyum } \\
\text { (Moric.) C. Koch }\end{array}$ & 74.2 & 0 & 0 & Arthrocnemetea fruticosie R. Tüxen et Oberdorfer, 1958
\end{tabular}

\begin{tabular}{llllll} 
(Moric.) C. Koch & & & \\
\hline CARYOPHYLLACEAE & Mesembryanthemum nodiflorum L. & 1.8 & 0 & 0 & Saginetea maritimae Westhoff, van Leeuwen \& Adriani, 1962
\end{tabular}

\begin{tabular}{llllll}
\hline AMARANTHACEAE & Beta vulgaris ssp. maritima L. & 1.4 & 1.6 & 0 & Asteretea tripolii Westhoff \& Beeftink in Westhoff, van Leeuwen \& Adriani, 1962
\end{tabular}

\begin{tabular}{llllll}
\hline ZYGOPHYLLACEAE & Peganum harmala L. & 1.2 & 9.4 & 0 & Pegano harmalae - Salsoletea vermiculatae Braun-Blanquet \& O. de Bolòs, 1958 \\
\hline
\end{tabular}

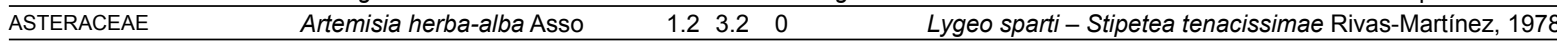

\begin{tabular}{llllll}
\hline BRASSICACEAE & Diplotaxis virgata (Cav.) DC. & 0 & 8.6 & 0 & \\
\hline & Stellarietea mediae (Braun-Blanquet, 1921) Tüxen, Lohmeyer \& Preising
\end{tabular}

\begin{tabular}{llllll}
\hline BRASSICACEAE & Neslia paniculata (L.) Desv. & 0 & 6.4 & 0 & $\begin{array}{r}\text { Stellarietea mediae (Braun-Blanquet, 19 } \\
\text { in Tüxen } 1950 \text { em. Schubert in Schubert, Hilbig \& Klotz, 1995 }\end{array}$
\end{tabular}

CARYOPHYLLACEAE Vaccaria hispanica (Mill.) Raushcert. $013.40 \quad$ Stellarietea mediae (Braun-Blanquet, 1921) Tüxen, Lohmeyer \& Preising

P in Tüxen 1950 em. Schubert in Schubert, Hilbig \& Klotz, 1995

\begin{tabular}{llllll}
\hline POACEAE & Avena sterilis L. & 0 & 13.6 & 0 & Stellarietea mediae (Braun-Blanquet, 1921) Tüxen, Lohmeyer \& Preising
\end{tabular}

\begin{tabular}{lcccccc}
\hline EUPHORBIACEAE & Euphorbia helioscopia L. & 0 & 17 & 0 & $\begin{array}{c}\text { Stellarietea mediae (Braun-Blanquet, 1921) Tüxen, Lohmeyer \& Preising } \\
\text { in Tüxen 1950 em. Schubert in Schubert, Hilbig \& Klotz, 1995 }\end{array}$ \\
\hline APIACEAE & $\begin{array}{c}\text { Torilis arvensis ssp. neglecta } \\
\text { (Rouy \& Camus) Thell. }\end{array}$ & 0 & 2.4 & 0 & &
\end{tabular}

$\begin{array}{lcccc}\text { APIACEAE } & \begin{array}{c}\text { Torilis arvensis ssp. neglecta } \\ \text { (Rouy \& Camus) Thell. }\end{array} & 0 & 2.4 & 0\end{array}$

\begin{tabular}{lccccc}
\hline PLANTAGINACEAE & Plantago afra L. & 0 & 3.4 & 0 & Stipo capensis - Brachypodietea distachyi (Braun-Blanquet, 1947) Brullo, 1985 \\
\hline
\end{tabular}

\begin{tabular}{llllll}
\hline APIACEAE & Eryngium ilicifolium Lam. & 0 & 4.2 & 0 & Tuberaria guttatae Braun-Blanquet, 1952 emend. Rivas-Martinez, 1978
\end{tabular}

\begin{tabular}{llllll}
\hline FABACEES & Medicago truncatula Gaertn. & 0 & 9 & 0 & Stipo capensis - Brachypodietea distachyi (Braun-Blanquet, 1947) Brullo, 1985 \\
\hline
\end{tabular}

\begin{tabular}{lllll}
\hline CARYOPHYLLACEAE & Silene cinerea Desf. & 0 & 2.6 & 0
\end{tabular}

\begin{tabular}{lccccc}
\hline BRASSICACEAE & $\begin{array}{c}\text { Cynoglossum tubiflorum (Murb.) } \\
\text { Greut. \& Burd. }\end{array}$ & 0 & 3.6 & 0
\end{tabular}

\begin{tabular}{llllll}
\hline FABACEES & Astragalus armatus ssp. armatus Willd. & 0 & 1.2 & 0
\end{tabular}

\begin{tabular}{lllll}
\hline POACEAE & Lygeum spartum L. & 0 & 2 & 0
\end{tabular}

\begin{tabular}{lcccc}
\hline POACEAE & Poa bulbosa L. & 0 & 10.8 & 0
\end{tabular}

\begin{tabular}{llcccc}
\hline POACEAE & Bromus hordeaceus ssp. hordeaceus L. & 0 & 31.4 & 0
\end{tabular}

\begin{tabular}{lllcl}
\hline POACEAE & Anisantha madritensis (L.) Nevski & 0 & 20 & 0
\end{tabular}

\begin{tabular}{llllll}
\hline ASPARAGACEAE & Muscari comosum (L.) Mill. & 0 & 1 & 0
\end{tabular}

\begin{tabular}{llllll}
\hline ASTERACEAE & Centaurea sicula (L.) Soják & 0 & 1.6 & 0
\end{tabular}

ASTERACEAE Galactites tomentosa Moench $\quad 0 \quad 0 \quad 1.4 \quad 0$

\begin{tabular}{lccccc}
\hline ASTERACEAE & Centaurea calcitrapa L. & 0 & 4.2 & 0 & Onopordetea acanthii ssp. acanthii Braun-Blanquet, 1964 em. Julve, 1993 \\
\hline PAPAVERACEES & Glaucium corniculatum (L.) Rudolph & 0 & 6.4 & 0 & Onopordetea acanthii ssp. acanthii Braun-Blanquet, 1964 em. Julve, 1993
\end{tabular}

\begin{tabular}{llllll}
\hline LAMIACEAE & Marrubium alysson L. & 0 & 1.6 & 0 & Onopordetea acanthii ssp. acanthii Braun-Blanquet 1964 em. Julve, 1993
\end{tabular}

\begin{tabular}{lllllll}
\hline BRASSICACEAE & Biscutella auriculata ssp. auriculata L. & 0 & 2 & 7 & Stipo capensis - Brachypodietea distachyi (Braun-Blanquet 1947) Brullo, 1985
\end{tabular}

\begin{tabular}{lllllll}
\hline BRASSICACEAE & Eruca vesicaria ssp. vesicaria & 0 & 2.4 & 8 & Stellarietea mediae (Braun-Blanquet, 1921) Tüxen, Lohmeyer \& Preising
\end{tabular}

\begin{tabular}{llllll} 
& (Miller) Thell. & & 2.4 & 8 & in Tüxen, 1950 em. Schubert in Schubert, Hilbig \& Klotz, 1995 \\
\hline PAPAVERACEAE & Papaver hybridum L. & 0 & 17.4 & 23 & Stellarietea mediae (Braun-Blanquet, 1921) Tüxen, Lohmeyer \& Preising
\end{tabular}

\begin{tabular}{llllc}
\hline BORAGINACEAE & Echium humile Desf. & 0 & 1.4 & 4 \\
\hline RESEDACEAE & Reseda arabica Boiss. & 0 & 1.4 & 9 \\
\hline MALVACEAE & Malva aegyptiaca L. & 0 & 3.8 & 3.8
\end{tabular}

ASTERACEAE $\quad$ Echinops spinosus ssp. bovei $\quad 0 \quad 4.618 \quad$ Onopordetea acanthii ssp. acanthii Braun-Blanquet, 1964 em. Julve, 1993

\begin{tabular}{llllll} 
& (Boiss.) Murb. & & & \\
\hline BORAGINACEAE & Echium plantagineum L. & 0 & 5.2 & 7 & Onopordetea acanthii ssp. acanthii Braun-Blanquet, 1964 em. Julve, 1993
\end{tabular}

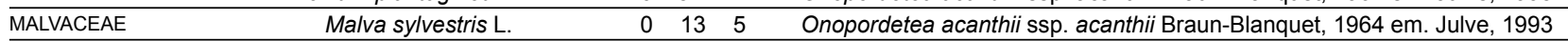

\begin{tabular}{llllll}
\hline GERANIACEAE & Erodium cicutarium (L.) L'Hérit. & 0 & 9 & 9 & Stipo capensis - Brachypodietea distachyi (Braun-Blanquet, 1947 ) Brullo, 1985 \\
\hline
\end{tabular}

\begin{tabular}{llllll}
\hline FABACEES & Vicia peregrina L. & 0 & 4.2 & 5.6 & Stipo capensis - Brachypodietea distachyi (Braun-Blanquet, 1947) Brullo, 1985
\end{tabular}

\begin{tabular}{llllll}
\hline POACEAE & Hordeum murinum L. & 0 & 6.8 & 35 & Saginetea maritimae Westhoff, van Leeuwen \& Adriani, 1962
\end{tabular}

$\begin{array}{llllll}\text { POACEAE } & - & 0 & 7 & 9 & \text { Agrostio stoloniferae - Arrhenatheretea elatioris ssp. elatioris }\end{array}$

$\begin{array}{lllll}\text { POACEAE } & 0 & 7 & 9 & \text { (Tüxen, 1937 em. 1970) de Foucault, 1984 }\end{array}$

\begin{tabular}{llllll}
\hline ASTERACEAE & Carthamus lanatus L. & 0 & 2.8 & 9 & Sisymbrietea officinalis Gutte \& Hilbig, 1975
\end{tabular}

\begin{tabular}{llllll}
\hline BRASSICACEAE & Sisymbrium runcinatum Lag. Ex DC. & 0 & 5.6 & 17 & Sisymbrietea officinalis Gutte \& Hilbig, 1975
\end{tabular}

\begin{tabular}{lllll}
\hline ASTERACEAE & Anacyclus clavatus (Desf.) Pers. & 0 & 8.4 & 8
\end{tabular}

\begin{tabular}{lllll}
\hline ASTERACEAE & Picris cupuligera (Durieu) Walp. & 0 & 1.8 & 12
\end{tabular}

\begin{tabular}{lllll}
\hline LAMIACEAE & Salvia verbenaca $L$. & 0 & 2.4 & 4
\end{tabular}

\begin{tabular}{lcccc} 
RESEDACEAE & Reseda alba L. & 0 & 0.6 & 12 \\
\hline PLANTAGINACEAE & Plantago albicans L. & 0 & 3.2 & 4
\end{tabular}

\begin{tabular}{lllll}
\hline ASTERACEAE & Scolymus hispanicus L. & 0 & 9.4 & 16
\end{tabular}

\begin{tabular}{lllll}
\hline ASTERACEAE & Silybum marianum (L.) Gaertn. & 0 & 0 & 7
\end{tabular}

\begin{tabular}{llllll}
\hline AMARANTHACEAE & Atriplex halimus L. & 0 & 0 & 5
\end{tabular}

\begin{tabular}{lllll}
\hline POACEAE & Anisantha sterilis (L.) Nevski & 0 & 0 & 31
\end{tabular}

\begin{tabular}{lllll}
\hline POACEAE & Anisantha rubens (L.) Nevski & 0 & 0 & 12
\end{tabular}

\begin{tabular}{lllll}
\hline POACEAE & Anisantha tectorum (L.) Nevski & 0 & 0 & 29
\end{tabular}

POACEAE Lolium rigidum Gaudin $\quad 0.004 .4$

\begin{tabular}{lllll} 
POACEAE & Lolium rigidum Gaudin & 0 & 0 & 8.4 \\
\hline ASTERACEAE & Calendula arvensis L. & 0 & 0
\end{tabular}

Dactylo glomeratae ssp. hispanicae - Brachypodietea retusi Julve, 1993

Dactylo glomeratae ssp. hispanicae - Brachypodietea retusi Julve, 1993 Lygeo sparti - Stipetea tenacissimae Rivas-Martínez, 1978

Onopordetea acanthii ssp. acanthii Braun-Blanquet,1964 em. Julve, 1993

Onopordetea acanthii ssp. acanthii Braun-Blanquet, 1964 em. Julve, 1993

Sarcocornietea fruticosae Braun-Blanquet \& Tüxen, 1943

ex A. \& O. de Bolòs in A. de Bolòs, 1950

Sisymbrietea officinalis Gutte \& Hilbig, 1975

Sisymbrietea officinalis Gutte \& Hilbig, 1975

Sisymbrietea officinalis Gutte \& Hilbig, 1975

Sisymbrietea officinalis Gutte \& Hilbig, 1975

\begin{tabular}{llll} 
ASTERACEAE & Calendula arvensis L. & 0 & 0 \\
\hline ASTERACEAE & Senecio leucanthemifolius ssp. & 0 & 0
\end{tabular}

\begin{tabular}{lllll} 
& poiretianus Poir. & & & \\
\hline ASTERACEAE & Hertia cheirifolia (L.) Kuntze & 2 & 0 & 24
\end{tabular}

\begin{tabular}{lllll}
\hline POACEAE & Piptatherum miliaceum (L.) Coss. & 0 & 0 & 15
\end{tabular}

Stellarietea mediae (Braun-Blanquet, 1921) Tüxen, Lohmeyer \& Preising in Tüxen, 1950 em. Schubert in Schubert, Hilbig \& Klotz, 1995

Saginetea maritimae Westhoff, van Leeuwen \& Adriani, 1962 
Appendix 3. Grasshoppers recorded in the three zones of Chott Tinsilt. The densities are expressed by adult numbers per $100 \mathrm{~m}^{2}$.

\begin{tabular}{|c|c|c|c|c|}
\hline Family & Species & Inner Zone & Middle Zone & Outer Zone \\
\hline Dericorythidae & Dericorys millierei Bonnet \& Finot, 1884 & 25.71 & 0 & 0 \\
\hline Acrididae & Calliptamus barbarus (Costa, 1836) & 3.5 & 12.33 & 2.67 \\
\hline Acrididae & Calliptamus wattenwylianus Pantel, 1896 & 3.3 & 7.96 & 1.96 \\
\hline Pyrgomorphidae & Pyrgomorpha cognata Krauss, 1877 & 0 & 1.62 & 0 \\
\hline Pamphagidae & Tmethis cisti cisti (Fabricius, 1787) & 0 & 6.04 & 0.25 \\
\hline Acrididae & Oedipoda caerulescens (Linnaeus, 1758) & 0 & 2.75 & 0.33 \\
\hline Pamphagidae & Ocneridia volxemii (Bolívar, 1878) & 0 & 9.08 & 5.25 \\
\hline Pamphagidae & Pamphagus cristatus Descamps \& Mounassif, 1972 & 0 & 0.42 & 1.87 \\
\hline Acrididae & Oedipoda miniata (Pallas, 1771) & 0 & 11.37 & 7.46 \\
\hline Acrididae & Sphingonotus azurescens (Rambur, 1838) & 0 & 3.33 & 1.29 \\
\hline Acrididae & Acrotylus patruelis (Herrich-Schäffer, 1838) & 0 & 2.42 & 0.75 \\
\hline Acrididae & Dociostaurus maroccanus (Thunberg, 1815) & 0 & 6.08 & 3.08 \\
\hline Acrididae & Dociostaurus jagoi Soltani, 1978 & 0 & 2.12 & 5.33 \\
\hline Acrididae & Oedaleus decorus (Germar, 1825) & 0 & 0.75 & 3.46 \\
\hline Acrididae & Aiolopus strepens (Latreille, 1804) & 0 & 0.29 & 1.67 \\
\hline Pyrgomorphidae & Pyrgomorpha conica (Olivier, 1791) & 0 & 0 & 2.17 \\
\hline Pamphagidae & Acinipe calabra (Costa, 1836) & 0 & 0 & 1.33 \\
\hline
\end{tabular}

